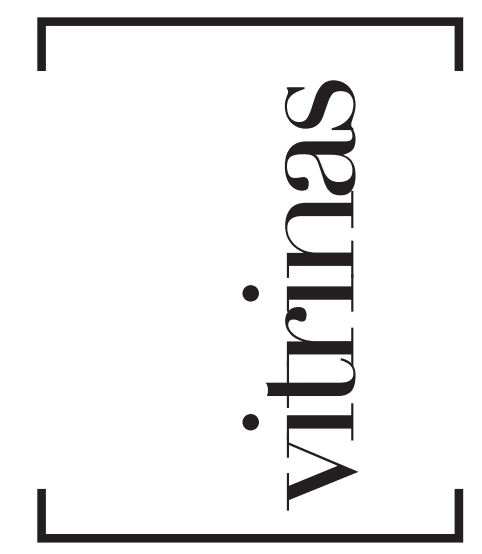

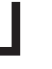

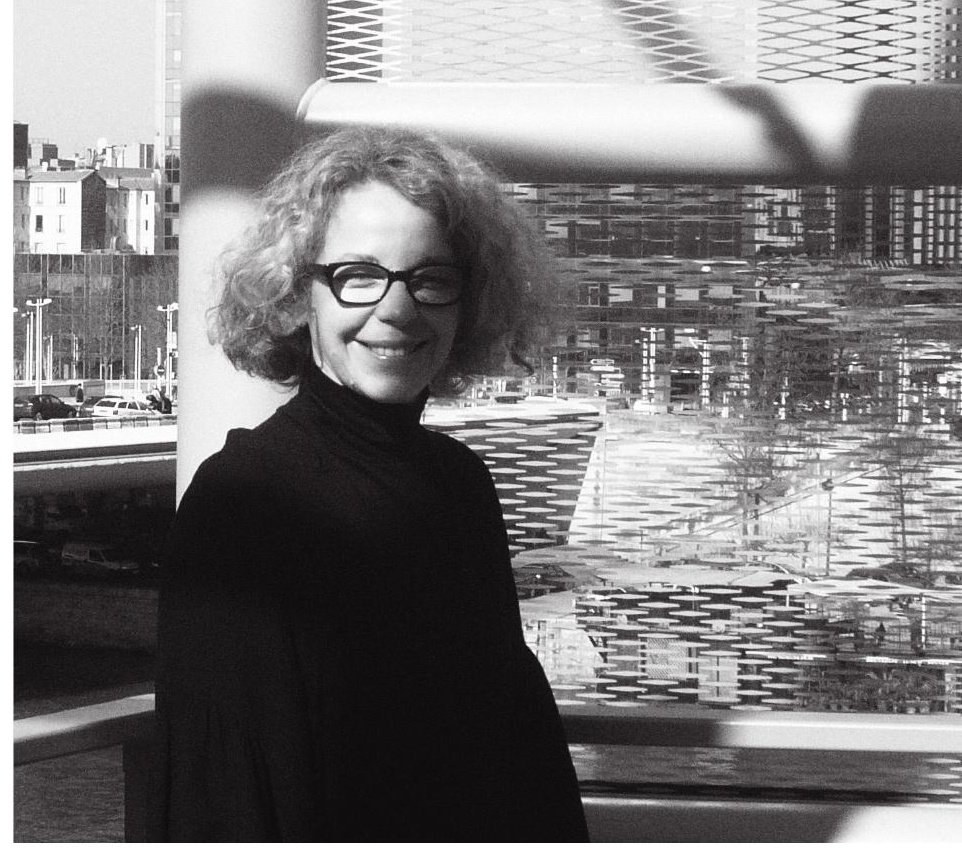

Françoise Sackrider, diretora no IFM do Programme Postgraduate de Management Mode et Design

\section{[ SYLVIA DEMETRESCO ]}

Professora da École Supérieure de Visual Merchandising, na Suiça. Editora da revista internacional de visual merchandising Inspiration; autora dos livros Vitrinas entre-vista: merchandising visual (Senac São Paulo, 2004) e Vitrinas em diálogos urbanos (Anhembi Morumbi, 2005).

Site: www.vitrina.com.br

E-mail: sylvia@vitrina.com.br

\title{
Lèche-vitrines um encontro... uma proposta de leitura
}

Qual a diferença entre um clube de futebol brasileiro e uma batata frita belga? Entre um macarron francês e um chocolate suiço? Como construir a exposição dos produtos que nos rodeiam? Onde encontrar a essência, o conceito para o desenvolvimento de novos projetos? Como são visíveis e sentidas as diferenças na singularidade do produto, na cultura de cada localidade? Quem estuda o quê? Quem escreve o quê? Onde se instala esta possibilidade de construção e sedução?

Num dia de sol e vento frio, fui à nova sede do Institut Français de la Mode (IFM), em Paris, ao encontro de Françoise Sackrider. Queríamos nos conhecer, saber exatamente o que cada uma faz, falarmos do novo livro, de novos projetos, enfim... conversarmos sobre Visual Merchandising.

Françoise Sackrider atua com Visual Merchandising na França, é diretora no IFM do Programme Postgraduate de Management Mode et Design que forma alunos para a gestão de marcas na indústria da moda, em marketing de produto, em distribuição, em comunicação e em Visual Merchandising, e também é a responsável pelo livro Lèche-vitrines: distribuition et merchandising visuel dans la mode - reeditado no final de 2008. Vale lembrar que lèche-vitrines é uma expressão francesa que podemos traduzir como admirar ou apreciar vitrinas. 


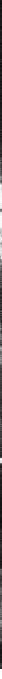

Institut Français de la Mode

No livro, um grupo de professores e pesquisadores que atuam diretamente nesse curso apontam e discutem como o Visual Merchandising tornou-se a melhor arma das novas empreitadas comerciais. Se o Visual Merchandising foi criado, inicialmente, pelas lojas de grandes superfícies, os autores indicam como na França esse sistema passou desses espaços para as lojas de vestuário e acessórios e evidenciam como os conceitos dos Grands Magasins, que emergiram no século XIX, influenciaram a paisagem francesa.

0 livro aponta os Estados Unidos como exemplo dos mais emblemáticos e o país que, até então, melhor desenvolveu as técnicas do Visual Merchandising com as marcas, tendo sempre em mente o produto. Relata como a Gap, a Zara e a H\&M, quando chegaram à França, na década de 1980, imprimiram sua assinatura e inquietação com o Visual Merchandising. E como a evolução da exposição dos produtos foi determinante e influenciou as marcas francesas como Etam, Pinki, Camaieu, Promod e a alta-costura de Chanel, Dior, Givenchy e Hermès. Importante ressaltar que a França sempre foi diferenciada no mundo da alta-costura e pioneira na exposição do mass market, mas não se destacava em Visual Merchandising. 0 Carrefour foi quem deixou as primeiras pegadas.

0 olhar dos autores nessa nova edição de Lèche-vitrines revela ainda qual é o valor do produto de moda, como dar unicidade à exposição, como trazer o reequilíbrio e a sobriedade na construção das cenografias que o exibem e como, atualmente, se desenvolve sua apresentação a partir do geral, existente nos supermercados, para a singularização necessária na dinâmica da moda.

0 importante parece ser compreender que não é só estar no mundo, fazer parte do mercado, mas comunicar de maneira crítica e sensível as características do produto que o tornam algo de especial! Expor uma bolsa, expor um vestido ou expor uma joia são maneiras de fazer ver diferentemente um produto, dar-lhe vida, e é disso que o Visual Merchandising se encarrega, de contar as histórias particulares de produtos por trás dos quais estão grandes astúcias.

\section{SAIBA MAIS}

SACKRIDER, Françoise; GUIDE, Gwenola; HERVE, Dominique. Lèche-vitrines: distribuition et merchandising visuel dans la mode. Paris: IFM/Regard, 2008.

IFM - Progamme Postgraduate de Management Mode et Design. Disponível

em: <http://www.ifm-paris.com/asp/fr2/acad_mgmt_1_0.asp>. 